\title{
Co-administration of vitamin E and atorvastatin improves insulin sensitivity via peroxisome proliferator-activated receptor $y$ in hyperlipidemic type 2 diabetic patients: a randomized double- blinded clinical trial
}

\section{Banafsheh Sadat Tabaei}

Zanjan University of Medical Sciences

Aliasghar Rahimian

Tehran University of Medical Sciences

Hadi Rostamkhani

Zanjan University of Medical Sciences

Neda Mousavi ( $\nabla$ neda.mousavi@zums.ac.ir)

Zanjan University of Medical Sciences

Ali Awsat Mellati

Zanjan University of Medical Sciences

Maryam Jameshorani

Zanjan University of Medical Sciences

\section{Research}

Keywords: vitamin E, Atorvastatin, peroxisome proliferator-activated receptor, insulin sensitivity, diabetes

Posted Date: April 9th, 2020

DOI: https://doi.org/10.21203/rs.3.rs-21468/v1

License: (c) (i) This work is licensed under a Creative Commons Attribution 4.0 International License.

Read Full License 


\section{Abstract}

Background: Contrary to the reports about the useful effects of atorvastatin on blood lipids and insulin sensitivity by up-regulation of peroxisome proliferative-activated receptor gamma (PPAR- $\gamma$ ) expression, to our knowledge, there is inconclusive results about vitamin E. Also, there is no study to assess coadministration of vitamin E and atorvastatin on PPAR-y mRNA expression, insulin sensitivity and lipid profile in diabetic patients. We compared this effect in hyperlipidemic subjects with type 2 diabetes mellitus (T2DM).

Methods: At the present randomized clinical trial (RCT), 30 T2DM women with hyperlipidemia were categorized into the treated group with $20 \mathrm{mg}$ atorvastatin plus $400 \mathrm{IU}$ vitamin E supplement $(\mathrm{n}=15)$ or atorvastatin plus placebo $(n=15)$ per day for 12 weeks. Anthropometric and biochemical measures were done at the baseline and after the 12-week intervention. PPAR-y mRNA expression was measured in the peripheral blood mononuclear cells (PBMCs) of all patients.

Results: After adjusting for the baseline measures, vitamin $E$ resulted in significant improvements in insulin sensitivity in terms of HOMA-IR $(-1.01 \pm 0.52$ vs. $-2.56 \pm 0.54, P=0.04)$ and serum insulin $(-0.55 \pm 0.35$ vs. $-6.5 \pm 1.3, P<0.001)$, compared with the atorvastatin plus placebo. Adjusted for the baseline variables, compared with the atorvastatin plus placebo, vitamin $E$ supplementation could upregulate PPAR- $\gamma$ mRNA expression $(\mathrm{OR}=5.4,95 \% \mathrm{Cl}=0.8-36.9, \mathrm{P}=0.04)$ in PBMC of T2DM women.

Conclusions: Vitamin E supplementation along with atorvastatin may improve insulin sensitivity through up-regulation of PPAR-y gene. More RCTs are needed to reach conclusive results.

Trial registration: The present study is registered under ClinicalTrials.gov Identifier no. IRCT20170918036256N1.

\section{Background}

Prevalence of type 2 diabetes Mellitus (T2DM) is quadrupled from 1980 to $2014{ }^{(1)}$. Approximately $60 \%$ of T2DM patients have hyperlipidemia ${ }^{(2)}$. Dyslipidemia and insulin resistance lead to micro- and macrovascular complications, which lead to morbidity and mortality in these patients ${ }^{(3)}$. The major primary approaches to control these risk factors are lifestyle manifestations and medications ${ }^{(4,5)}$. Statin therapy is considered as the cornerstone of clinician's efforts toward prevention of late complications in patients with T2DM ${ }^{(6)}$. Recently, recognition and detailed conception of the molecular events that control metabolic pathways help to the development of drugs targeting the responsible elements in therapeutic events ${ }^{(7,8)}$.

Peroxisome proliferator-activated receptors (PPARs) are one of the transcriptional factors, which have been identified as the regulators for the expression of several genes involved in metabolism ${ }^{(9)}$. Recently, the PPAR family ligands have drawn great notice in the management of risk factors of T2DM (4). PPAR- $y$ expresses at the highest level in adipocytes and regulates their differentiation, as well as fatty acid 
uptake and accumulation ${ }^{(10,11)}$. PPAR-y upregulates the genes involved in cholesterol efflux, anticoagulants, and antioxidants. Also, it improves insulin sensitivity and leads to reduced insulin and glucose plasma levels ${ }^{(12,13)}$. Synthetic PPAR-y ligands are currently used to treat hyperlipidemia and T2DM ${ }^{(14)}$. Statins are PPAR-y activators, which have anti-inflammatory effects by suppression of proinflammatory cytokines and prevent the accumulation of cholesterol ${ }^{(15)}$. Vitamin $E$ is a fat soluble antioxidant which includes tocopherols and tocotrinoles ${ }^{(16)}$. Alpha tocopherol is the major form of vitamin $E$ in the plasma and tissue ${ }^{(17)}$. It is reported that a-tocopherol activates expression of PPAR-Y gene in the cancerous cells ${ }^{(18)}$. Despite some evidence, although scarce, no study, to our knowledge, has evaluated whether vitamin E supplementation with atorvastatin results in a greater useful effect on insulin sensitivity and lipid profile in T2DM patients with hyperlipidemia or not. Then, we designed the present study to assess the effects of atorvastatin therapy with and/or without vitamin $\mathrm{E}$ with considering the PPAR-y mRNA expression as a primary outcome, as well as insulin sensitivity and lipid profile as the secondary outcomes, in T2DM patients with hyperlipidemia. We hypothesized that vitamin E supplementation has synergistic effect with atorvastatin on lipid profile and insulin sensitivity via PPAR pathway.

\section{Methods}

\section{Study enrolment}

Totally, 30 T2DM women with hyperlipidemia were gathered between July 2017 and March 2018 from T2DM patients who were referring to the Vali-e-Asr Hospital, Zanjan, Iran. Women aged 18-65 y, BMI of $25-35 \mathrm{~kg} / \mathrm{m}^{2}, 7 \%<\mathrm{HbA} 1 \mathrm{c}<9 \%$, who needed $20 \mathrm{mg}$ atorvastatin per day to control LDL.C level were included. The exclusion criteria were as follows: intake of thiazolidinedione, vitamin E or any supplementation within the three month ago, pregnancy and/or breast-feeding, weight loss more than $10 \%$ during the past 6 month, hypo/hyper thyroids, intake of weight loss drugs, smoking, diagnosis of any chronic diseases.

\section{Study planning}

This was a randomized, double-blinded, controlled trial to study the effects of atorvastatin and vitamin $\mathrm{E}$ co-administration on the anthropometric measures, fasting blood sugar (FBS), serum insulin concentrations and sensitivity, lipid profiles, and PPAR-y mRNA expression in T2DM patients. Thirty eligible women were randomly assigned by block randomization method to one of the 2 groups: atorvastatin and placebo $(A+P)$ group $(n=15)$ received $20 \mathrm{mg}$ of atorvastatin (Jalinus Arya Co, Iran) plus placebo $(25 \mu \mathrm{g} / \mathrm{d}$ as lactose; Jalinus Arya Co, Iran) and/or atorvastatin plus vitamin $E(A+E)$ group ( $n=$ 15) received $20 \mathrm{mg}$ atorvastatin (Jalinus Arya Co, Iran) plus $400 \mathrm{IU}$ vitamin E (Jalinus Arya Co. Iran) for 12 weeks. The placebo was similar to vitamin $E$ in shape, color and packaging. (Fig. 1)

\section{Lifestyle}


Participants requested don't change their dietary habits. Diets were checked and controlled by an expert dietitian. Dietary intake was assessed by 3 days food records at the end of each month. Supplement consumption was monitored once a week by telephone interviews and double checked by using the food record questionnaires. Physical activity level was assessed by International Physical Activity questionnaire (IPAQ) at the beginning of the study.

\section{Measurements}

\section{Anthropometric measures}

Body weight and height were measured by the standard scales. BMI (Body Mass Index) was calculated according to the weight/ height ${ }^{2}\left(\mathrm{~kg} / \mathrm{m}^{2}\right)$. Fat distribution was measured by waist to hip ratio (WHR) in which waist and hip circumferences were gathered from the halfway between the lower rib-the iliac crest and hip from the maximum circumference over the buttocks. All measures (except height) were taken at baseline and after 12 week.

\section{Biochemical parameters}

$20 \mathrm{ml}$ of fasting blood samples from antecubital vein were collected at baseline and at $12 \mathrm{wk} .10 \mathrm{ml}$ of samples were gathered in EDTA-coated sterile tubes and $10 \mathrm{ml}$ in the regular tubes.

To eliminate the effect of sex hormones on lipid profile, sampling was not performed between days 1 and 5 of the menstrual cycle.

Blood samples in the regular tubes were centrifuged for $20 \mathrm{~min}(3000 \mathrm{~g})$ and the serum samples were frozen. Serum lipid profile, FBS, 2-h plasma glucose (2hPG), HbA1c and insulin levels were measured by an enzymatic method (Pars Azmoon Co. kit, Tehran, Iran) using Hitachi autoanalyzer. Serum insulin was measured by ELISA (Immunotech Co. kit); and homeostasis model assessment for insulin resistance (HOMA-IR) was calculated by the below formula (fasting insulin $(\mathrm{mU} / \mathrm{L}) \times \mathrm{FBS}(\mathrm{mmol} / \mathrm{L})) / 405)$.

\section{PBMC isolation and gene expression}

Samples in the EDTA-containing tubes were diluted with PBS (equal volume) in Ficolls. Ficolls were centrifuged for $40 \mathrm{~min}$ at $800 \mathrm{~g}$ at $4{ }^{\circ} \mathrm{C}$ and PBMCs were isolated according to the density gradient. Then, this layer washed with PBS and centrifuged again for $10 \mathrm{~min}$ at $600 \mathrm{~g}$ at the same temperature. Total mRNA was extracted using RNX-plus kits (Sinaclon, EX6101) according to the kit's guideline. Quantity and quality of the extracted RNA was assessed at $260 \mathrm{~nm}$ with a NanoDrop (Wilmington, DE, USA), and agarose gel electrophoresis, respectively. Finally, cDNA was synthesized according to the Takara kit (Takara Bio, Inc., Japan) in $20 \mu \mathrm{l}$ volumes. Gene expression was measured in duplicated manner by the RT-PCR method performed in an ABI StepOne sequence detection system (Applied Biosystems, California, USA). Mixture contained $1 \mu \mathrm{l}$ of CDNA, $10 \mathrm{pmol}$ of each forward and reverse primers and the SYBR Green I Master Mix (Roche). Primers were designed using the Gene Runner software. GAPDH was considered as housekeeping gene at this sequence: 5'-ACCATGAGAAGTATGACAAC-3' and 3'-TGAGTCCTTCCACGATACC- 
5'. PPAR-y primers were as follow: 5'-GCCTTTTGGTGACTTTATGGAG-3' and 3'CTTGTAGCAGGTTGTCTTGAATG-5'.

A Ct standard deviation $<1$ was considered the stability for the GAPDH gene as an appropriate control (19). The amplification profile included one cycle at $95^{\circ} \mathrm{C}$ for $5 \mathrm{~min}$ and 40 two-step cycles at $93^{\circ} \mathrm{C}$ for $30 \mathrm{~s}$ and 40 one-step cycles at $72^{\circ} \mathrm{C}$ for $45 \mathrm{~s}$. The results were analyzed by the LinRegPCR software (version 11.0).

\section{Serum vitamin E measurment}

Serum vitamin E levels as a-tocopherol was measured by HPLC method (Knauer, Germany). Standards including alpha tocopherol and tocopherol acetate were purchased from Sigma-Aldrich (Tokyo- Japan). A $\mathrm{C}_{18}$ column $(250 \mathrm{~mm} \times 4.6 \mathrm{~mm})$ was used for alpha-tocopherol separation. Methanol was used as the mobile phase with $0.8 \mathrm{ml} / \mathrm{min}$ flow rate, 53 bar pressure and $30^{\circ} \mathrm{C}$ temperature. The wavelength-range scanned was $190-540 \mathrm{~nm}$.

Isolated serum samples from FBS (10 min, $3500 \mathrm{gr}$ ) were allocated into micro tubes. To prevent oxidation of vitamin E, micro tubes were packed in foils and filled by nitrogen. $400 \mu \mathrm{l}$ of alcohols $(200 \mu \mathrm{l}$ of ethanol and $200 \mu \mathrm{l}$ of methanol) were added to $200 \mu \mathrm{l}$ of each serum sample in the polypropylene tubes. The mixture was vortexed for $10 \mathrm{~s}$. Then, $500 \mu \mathrm{l}$ of hexane was added to each tube and vortexed for $60 \mathrm{~s}$. Samples were centrifuged ( $5 \mathrm{~min}, 4500 \mathrm{~g}$ ) and supernatants were collected the other micro tubes (procedure was repeated three times). Methanol $(200 \mu \mathrm{l})$ was added to the dried hexane phase (45$50^{\circ} \mathrm{C}$ ) and $150 \mu \mathrm{l}$ of dilution was injected to the HPLC system, finally. Peak areas of tocopherols were integrated at $280 \mathrm{~nm}$. After each sample analysis, the column was washed with propan-2-ol $(1 \mathrm{ml} / \mathrm{min}$ for 60 min at $45^{\circ} \mathrm{C}$ ) to ensure reproducible retention on the column.

\section{Statistics}

According to the previous study ${ }^{(20)}$, with the standard deviation (SD) difference of $40.9 \mathrm{mg} / \mathrm{dl}$ for LDL.C, power of $80 \%$ in a two-sided test and $a=0.05$ (type I error), the sample size computed 12 patient in each group. With $10 \%$ dropout, we set the participant target at 15 patients.

IBM SPSS Statistics software (version 16; IBM Corp) was used for analysis. Data were reported as means $\pm S E$. $P<0.05$ was considered significant. At the first, normal distribution of data was assessed by the K-S test. Between-group analysis was performed by the independent sample t-test. Within-group differences before and after the study was analyzed by the paired t-tests. To adjust the effect of baseline variables on the outcomes, ANCOVA test was used. Fold change of PPAR y expression was assessed by the Logistic regression model adjusted to the baseline measures and treatments.

\section{Results}

Thirty T2DM-proven women followed the study up to the end. All participants were married. Energy, nutrient intake and physical activity level had not significant difference between the two groups and 
within the groups $(p>0.05)$.

Variables had not significantly difference at the baseline (Table 1). At the A + P group, serum LDL.C level was significantly decreased after 12 week of intervention $(p=0.006)$. At the $A+E$ group, serum insulin level $(p=0.001), \operatorname{HbA} 1 c(p=0.04), 2 h P G(p=0.04)$, LDL.C $(P=0.03), T G(P=0.02), T C(P=0.01)$, and HOMA-IR $(P=0.001)$ were significantly decreased at the end compared to the baseline. PPAR-y mRNA expression was significantly increased after 12 week in the both treated groups $(p<0.001$ and $p<0.001$, respectively) (Table 2). 
Table 1

Patient characteristics before the intervention

\begin{tabular}{|c|c|c|c|c|}
\hline \multirow{2}{*}{\multicolumn{2}{|c|}{ Variables }} & \multicolumn{2}{|l|}{ Groups } & \multirow[t]{2}{*}{$P$ value } \\
\hline & & $A+P$ & $A+E$ & \\
\hline \multicolumn{2}{|c|}{ Age, yr } & $50.6 \pm 1.1^{1}$ & $50.4 \pm 1.4$ & 0.9 \\
\hline \multicolumn{2}{|c|}{ Time of T2DM, yr } & $4.7 \pm 1.3$ & $5.8 \pm 1.3$ & 0.56 \\
\hline \multicolumn{2}{|c|}{ Energy, kcal } & $1960.1 \pm 210.5$ & $1917 \pm 312.1$ & 0.5 \\
\hline \multirow[t]{3}{*}{ PA, \% } & Low & $59.9 \%$ & $61.5 \%$ & \multirow[t]{3}{*}{0.4} \\
\hline & Moderate & $40.1 \%$ & $38.5 \%$ & \\
\hline & High & - & - & \\
\hline \multicolumn{2}{|c|}{$\mathrm{BMI}, \mathrm{kg} / \mathrm{m}^{2}$} & $27.1 \pm 0.9$ & $26.8 \pm 0.5$ & 0.6 \\
\hline \multicolumn{2}{|l|}{ WHR } & $0.97 \pm 0.01$ & $0.96 \pm 0.01$ & 0.64 \\
\hline \multicolumn{2}{|c|}{ FBS, mg/dl } & $177.4 \pm 19.6$ & $154.8 \pm 15.2$ & 0.37 \\
\hline \multicolumn{2}{|c|}{$2 \mathrm{hPG}, \mathrm{mg} / \mathrm{dl}$} & $254.5 \pm 31.9$ & $263.7 \pm 31.2$ & 0.84 \\
\hline \multicolumn{2}{|c|}{$\mathrm{HbA} 1 \mathrm{c}, \%$} & $7.6 \pm 0.4$ & $7.3 \pm 0.4$ & 0.67 \\
\hline \multicolumn{2}{|c|}{ HDL cholesterol, mg/dl } & $46.9 \pm 4.3$ & $48.7 \pm 3.1$ & 0.74 \\
\hline \multicolumn{2}{|c|}{ LDL cholesterol, mg/dl } & $101.5 \pm 7.2$ & $98.1 \pm 7.7$ & 0.75 \\
\hline \multicolumn{2}{|c|}{$\mathrm{TC}, \mathrm{mg} / \mathrm{dl}$} & $204.9 \pm 16.02$ & $201.2 \pm 11.9$ & 0.85 \\
\hline \multicolumn{2}{|c|}{$\mathrm{TG}, \mathrm{mg} / \mathrm{dl}$} & $192.1 \pm 25.9$ & $206 \pm 20.3$ & 0.68 \\
\hline \multicolumn{2}{|c|}{ Insulin, $\mu \mathrm{U} / \mathrm{L}$} & $10.5 \pm 2.7$ & $12.5 \pm 2.5$ & 0.6 \\
\hline \multicolumn{2}{|c|}{ HOMA-IR } & $4.9 \pm 1.6$ & $4.5 \pm 0.93$ & 0.82 \\
\hline \multicolumn{2}{|c|}{ PPAR-y } & 1 & $1.02 \pm 0.1$ & 0.85 \\
\hline \multicolumn{2}{|c|}{ Vitamin $\mathrm{E}, \mathrm{mg} / \mathrm{L}$} & $9.03 \pm 0.6$ & $9.5 \pm 0.2$ & 0.71 \\
\hline \multicolumn{5}{|c|}{$\begin{array}{l}\text { WHR, waist to hip ratio; FBS, fasting blood sugar; 2hPG: } 2 \text { hour plasma glucose; HbA1c: glycosylated hemoglobin; TC, total } \\
\text { cholesterol; TG, triglyceride; PPAR-Y: peroxisome proliferator-activated receptor; P, placebo; A: atorvastatin }\end{array}$} \\
\hline \multicolumn{5}{|c|}{${ }^{1}$ Means \pm SE (all such values) } \\
\hline
\end{tabular}


Table 2

Anthropometric and biochemical measurements at baseline and week 12

\begin{tabular}{|c|c|c|c|c|c|}
\hline \multirow[t]{2}{*}{ Variables } & \multicolumn{2}{|l|}{$A+P$} & \multicolumn{2}{|l|}{$A+E$} & \multirow[t]{2}{*}{ p value } \\
\hline & Baseline & Week 12 & Baseline & Week 12 & \\
\hline Energy, kcal & $1960.1 \pm 210.5$ & $1870.1 \pm 206.2$ & $1917 \pm 312.1$ & $1887 \pm 428.6$ & \multirow[t]{2}{*}{0.7} \\
\hline$p$ value $^{\dagger}$ & 0.32 & & 0.6 & & \\
\hline $\mathrm{BMI}, \mathrm{kg} / \mathrm{m}^{2}$ & $27.1 \pm 0.9$ & $26.8 \pm 0.8$ & $26.8 \pm 0.5$ & $26.5 \pm 0.5$ & \multirow[t]{2}{*}{0.8} \\
\hline$p$ value & 0.26 & & 0.2 & & \\
\hline WHR & $0.97 \pm 0.01$ & $0.96 \pm 0.01$ & $0.96 \pm 0.01$ & $0.95 \pm 0.1$ & \multirow[t]{2}{*}{0.9} \\
\hline$p$ value & 0.28 & & 0.36 & & \\
\hline FBS, mg/dl & $177.4 \pm 19.6$ & $152 \pm 11.6$ & $154.8 \pm 15.2$ & $134.3 \pm 8.1$ & \multirow[t]{2}{*}{0.2} \\
\hline $\mathrm{p}$ value & 0.08 & & 0.2 & & \\
\hline 2hPG, mg/dl & $254.5 \pm 31.9$ & $222.7 \pm 32.9$ & $263.7 \pm 31.2$ & $177.1 \pm 26.5$ & \multirow[t]{2}{*}{0.3} \\
\hline$p$ value & 0.09 & & 0.04 & & \\
\hline $\mathrm{HbA} 1 \mathrm{c}, \%$ & $7.6 \pm 0.42$ & $7.3 \pm 0.4$ & $7.3 \pm 0.4$ & $6.7 \pm 0.26$ & \multirow[t]{2}{*}{0.2} \\
\hline$p$ value & 0.16 & & 0.04 & & \\
\hline HDL.C, mg/dl & $46.9 \pm 4.3$ & $50.4 \pm 3.4$ & $48.7 \pm 3.1$ & $50.6 \pm 4.2$ & \multirow[t]{2}{*}{0.9} \\
\hline$p$ value & 0.18 & & 0.66 & & \\
\hline LDL.C, mg/dl & $101.5 \pm 7.2$ & $78.5 \pm 5.1$ & $98.1 \pm 7.7$ & $80.2 \pm 3.8$ & \multirow[t]{2}{*}{0.8} \\
\hline$p$ value & 0.006 & & 0.03 & & \\
\hline $\mathrm{TC}, \mathrm{mg} / \mathrm{dl}$ & $204.9 \pm 16$ & $174 \pm 16.9$ & $201.2 \pm 11.9$ & $168 \pm 4.8$ & \multirow[t]{2}{*}{0.7} \\
\hline$p$ value & 0.05 & & 0.01 & & \\
\hline $\mathrm{TG}, \mathrm{mg} / \mathrm{dl}$ & $192.1 \pm 25.9$ & $170.3 \pm 3.3$ & $206 \pm 20.3$ & $151 \pm 20.9$ & \multirow[t]{2}{*}{0.5} \\
\hline$p$ value & 0.3 & & 0.02 & & \\
\hline Insulin, $\mu \mathrm{U} / \mathrm{L}$ & $10.5 \pm 2.7$ & $9.9 \pm 2.5$ & $12.5 \pm 2.5$ & $6 \pm 1.4$ & 0.2 \\
\hline \multicolumn{6}{|c|}{$\begin{array}{l}\text { WHR, waist to hip ratio; FBS, fasting blood sugar; 2hPG: } 2 \text { hour plasma glucose; HbA1c: glycosylated hemoglobin; TC, total } \\
\text { cholesterol; TG, triglyceride; PPAR-Y: peroxisome proliferator-activated receptor; P, placebo }\end{array}$} \\
\hline${ }^{\dagger} p$ values are relat & differences in each $g$ & up from baseline up & he end; evaluated & ired sample t-test. & \\
\hline
\end{tabular}




\begin{tabular}{|c|c|c|c|c|c|}
\hline p value & 0.15 & & 0.001 & & \multirow{3}{*}{0.1} \\
\hline HOMA-IR & $4.9 \pm 1.6$ & $3.9 \pm 1.2$ & $4.5 \pm 0.93$ & $2 \pm 0.49$ & \\
\hline p value & \multicolumn{2}{|l|}{0.08} & \multicolumn{2}{|l|}{0.001} & \\
\hline PPAR-Y & 1 & $2.95 \pm 0.27$ & $1.02 \pm 0.1$ & $5.3 \pm 0.54$ & \multirow[t]{2}{*}{0.001} \\
\hline$p$ value & \multicolumn{2}{|l|}{$<0.001$} & \multicolumn{2}{|l|}{$<0.001$} & \\
\hline Vitamin E, mg/L & $9.03 \pm 0.6$ & $7.89 \pm 1.02$ & $9.5 \pm 1.2$ & $15.9 \pm 1.3$ & \multirow[t]{2}{*}{$<0.001$} \\
\hline p value & \multicolumn{2}{|l|}{0.31} & \multicolumn{2}{|l|}{$<0.001$} & \\
\hline \multicolumn{6}{|c|}{$\begin{array}{l}\text { WHR, waist to hip ratio; FBS, fasting blood sugar; 2hPG: } 2 \text { hour plasma glucose; HbA1c: glycosylated hemoglobin; TC, total } \\
\text { cholesterol; TG, triglyceride; PPAR-Y: peroxisome proliferator-activated receptor; P, placebo }\end{array}$} \\
\hline \multicolumn{6}{|c|}{${ }^{\dagger} \mathrm{p}$ values are related to the differences in each group from baseline up to the end; evaluated by paired sample $t$-test. } \\
\hline
\end{tabular}

After 12 week, BMI in the A + E group was significantly reduced, compared to the A + P group $(p=0.02)$. PPAR-y gene expression was significantly up-regulated at the $A+E$, compared to the $A+P$ group $(p=$ 0.001). Serum vitamin $E$ levels was significantly higher in the $A+E$ than $A+P$ group $(p<0.001)($ Table 2$)$.

Adjusting to the baseline measures, serum insulin level and HOMA-IR were significantly decreased at the $A+E$ compared with $A+P$ group, adjusted to the baseline variables $(-6.5 \pm 1.3$ vs. $-0.55 \pm 0.35, p<0.001$ and $-2.5 \pm 0.54$ vs. $-1.01 \pm 0.52$, $p=0.04$, respectively). PPAR- $\gamma$ mRNA expression was significantly upregulated at the $A+E$ than $A+P$ group ( $4.3 \pm 0.5$ vs. $1.9 \pm 0.27, p=0.001$ ), adjusted for baseline measures. Serum HbA1c, 2hPG, TG, and TC more decreased in the A + E than A + P group, but these changes were not significant (Table 3). 
Table 3

Mean changes from baseline up to the end of intervention between treatment groups

\begin{tabular}{|c|c|c|c|}
\hline Variables & $A+P$ & $A+E$ & p value ${ }^{\dagger}$ \\
\hline $\mathrm{BMI}, \mathrm{kg} / \mathrm{m}^{2}$ & $-0.21 \pm 0.17$ & $-0.63 \pm 0.11$ & 0.06 \\
\hline WHR & $-0.005 \pm 0.004$ & $0.003 \pm 0.002$ & 0.15 \\
\hline $\mathrm{FBS}, \mathrm{mg} / \mathrm{dl}$ & $-25.4 \pm 13.1$ & $-20 \pm 15$ & 0.8 \\
\hline $2 \mathrm{hPG}, \mathrm{mg} / \mathrm{dl}$ & $-31.8 \pm 17.2$ & $-86.6 \pm 37$ & 0.2 \\
\hline $\mathrm{HbA} 1 \mathrm{c}, \%$ & $-0.24 \pm 0.16$ & $-0.64 \pm 0.27$ & 0.23 \\
\hline HDL cholesterol, mg/dl & $3.5 \pm 2.4$ & $1.9 \pm 4.1$ & 0.7 \\
\hline LDL cholesterol, mg/dl & $-23 \pm 6.4$ & $-17.9 \pm 7.1$ & 0.6 \\
\hline $\mathrm{TC}, \mathrm{mg} / \mathrm{dl}$ & $-30.9 \pm 14$ & $-33.2 \pm 10.6$ & 0.89 \\
\hline $\mathrm{TG}, \mathrm{mg} / \mathrm{dl}$ & $-21.8 \pm 22.1$ & $-55 \pm 19.8$ & 0.3 \\
\hline Insulin, $\mu \mathrm{U} / \mathrm{L}$ & $-0.55 \pm 0.35$ & $-6.5 \pm 1.3$ & $<0.001$ \\
\hline HOMA-IR & $-1.01 \pm 0.52$ & $-2.5 \pm 0.4$ & 0.04 \\
\hline PPAR-Y & $1.9 \pm 0.27$ & $4.3 \pm 0.5$ & 0.001 \\
\hline Vitamin E, mg/L & $-1.1 \pm 1.05$ & $6.4 \pm 1.1$ & $<0.001$ \\
\hline \multicolumn{4}{|c|}{$\begin{array}{l}\text { WHR, waist to hip ratio; FBS, fasting blood sugar; } 2 \mathrm{hPG}: 2 \text { hour plasma glucose; HbA1c: glycosylated hemoglobin; TC, total } \\
\text { cholesterol; TG, triglyceride; PPARY: peroxisome proliferator-activated receptor; P, placebo }\end{array}$} \\
\hline \multicolumn{4}{|c|}{$\begin{array}{l}{ }_{\mathrm{P}} \text { values are for the atorvastatin plus vitamin Supplemented group relative to the atorvastatin plus placebo by using an ANCOVA } \\
\text { with baseline values as covariate. }\end{array}$} \\
\hline
\end{tabular}

According to the result of logistic regression model, PPAR- $y$ mRNA expression was significantly upregulated at the $A+E$ compared with the $A+P$ group after adjusting for the baseline measure as covariate $(\mathrm{OR}=5.4,95 \% \mathrm{Cl}=0.8-36.9, \mathrm{p}=0.04)$.

\section{Discussion}

To our knowledge, this is the first RCT performed to assess the effects of co-administration of vitamin E with atorvastatin on insulin sensitivity, blood glucose and lipids in the T2DM patients with hyperlipidemia. PPAR-y mRNA expression was assessed as the involved pathway in this effect. Our results suggest that atorvastatin along with vitamin E supplementation compared with atorvastatin alone may have beneficial effect on insulin sensitivity by regulation of serum insulin and HOMA-IR through PPAR- $\gamma$ mRNA up-regulation. Serum HbA1c, 2hPG, TG, and TC more decreased in the A+E than A+P 
group, but these changes were not statistically significant. We think this may have been due to not enough sample size which make the present study as a pilot one and a larger sample is needed in the future studies.

PPARs belong to the superfamily of nuclear receptors (NRs), which bind to the ligand and then heterodimerize with a retinoid-X-receptor, finally bind to peroxisome proliferative-response element (PPRE) to initiate signaling pathways ${ }^{(9,21)}$. PPARs have three isotypes including $\gamma$, a and $\beta / \delta$ which have tissue-

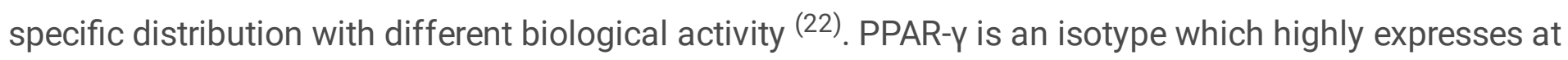
the adipose tissue and regulates gene expression of lipoprotein lipase, glucose transporters such as GLUT4 and adiponectin ${ }^{(23)}$. At the present study, we showed that vitamin E supplementation along with atorvastatin increases PPAR- $\gamma$ gene expression which is associated with lower insulin resistance. Our result is in agreement with the previous animal study which vitamin E supplementation $(50 \mathrm{mg} / \mathrm{kg})$ increased PPAR-y level in aortae of rabbits fed a cholesterol-rich diet ${ }^{(24)}$. They concluded that the protection effect of vitamin $E$ against atherosclerosis is related to the increase in ATP-binding cassette transporter A1 (ABCA1) gene expression which is a target gene for PPAR- $\gamma$.

The effect of $10 \mathrm{mg} / \mathrm{kg}$ d oral atorvastatin was compared with the $10 \mathrm{mg} / \mathrm{kg}$ d pioglitazone on PPAR- $Y$ gene expression in the heart of rats after a 3-day pretreatment ${ }^{(25)}$. Results showed that both of them upregulated PPAR-y gene expression via increase in myocardial 15-deoxy-prostaglandin J2 (15DPGJ2) levels in the rat myocardium. Tocotrienols enhanced the ligand-binding domains of PPARa with the receptor-interacting motif of PPAR-y coactivator-1a (PGC-1a) interaction. Also, they improved whole body glucose usage and insulin sensitivity by up-regulation of PPAR-y target genes (14). One cell culture study showed that vitamin $E$, both $a$ and $y$-tocopherol, up-regulates adiponectin expression at mRNA and protein level via a mechanism that increases PPAR- $\gamma$ mRNA through increase in 15DPGJ, as an endogenous ligand ${ }^{(26)}$.

The combination effect of atorvastatin plus vitamin E was studied in dialysis patients ${ }^{(27)}$. Results showed that atorvastatin is effective in the plasma TC, TG, LDL, apo-lipoprotein B and oxidized LDL reduction in these patients. Adding the alpha-tocopherol to atorvastatin had additional value on in vitro LDL oxidization. Our results are in contrast with this study. At our study, mean changes of TG and TC were higher in the atorvastatin plus vitamin $\mathrm{E}$ group than atorvastatin alone, but these changes were not significant. This inconclusive result may be due to various diseases. In one study, the effects of pitavastatin and atorvastatin compared on glycemic control and insulin sensitivity in type 2 diabetic patients with hypercholesterolemia ${ }^{(28)}$. Results showed that with the similar effects on lipid profile, mean changes in $\mathrm{HbA} 1 \mathrm{c}$ was significantly higher in the pitavastatin than atorvastatin-treated group. Also, pitavastatin lowered the glycoalbumin, FBS and HOMA-IR, significantly. The present study had the same results. Atorvastatin plus vitamin $\mathrm{E}$ had more effect in serum insulin and HOMA-IR than atorvastatin treatment, alone. 
Another human study assessed the effect of daily supplementation of 800 IU vitamin E in type 2 diabetic patients for 12 week ${ }^{(29)}$. They concluded that vitamin E supplementation can't improve FBG, lipid profile, $\mathrm{HbA1c}$, serum insulin, and blood pressure in these patients. Patients didn't receive any drug for lipid control. Vitamin E effect on blood glucose control is controversial. One study showed that consumption

of $1600 \mathrm{IU} /$ day a-tochopherol reduced $\mathrm{HbA} 1 \mathrm{c}$ levels, significantly ${ }^{(30)}$. Another study on type 1 diabetic patients has shown this reduction by $100 \mathrm{IU}$ vitamin E supplements ${ }^{(31)}$. Other studies with 600 and

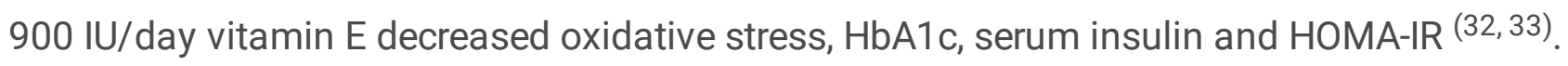

\section{Conclusions}

Co-administration of vitamin E with atorvastatin reduced insulin resistance and increased PPAR- $\gamma$ mRNA expression than atorvastatin, alone. Although more studies with larger samples are needed. Also, recognition of other signaling pathways and target genes related to PPAR- $\gamma$ in lipid and glucose metabolism are needed to reach concise results.

\section{Declarations}

Ethics approval and consent to participate: The ethic committee of Zanjan University of Medical Sciences, Zanjan, Iran, ethically approved the study. Patients signed the consent form before participation (ZUMS.REC.1395.268).

Consent for publication: Not applicable.

Availability of data and materials: Not applicable.

Competing interests: Not applicable.

Funding: The present study was financially supported by the Metabolic Diseases Research Center, Zanjan University of Medical Sciences, Zanjan, Iran.

Author's contribution: The authors' responsibilities were as follows: Banafsheh Sadat Tabaei, Seyedeh Neda Mousavi, Maryam Jamehshorani and Ali Awsat Mellati: conceived and designed the study protocol and provided administrative, technical and material support. Banafsheh Sadat Tabaei, Aliasghar Rahimian and Hadi Rostamkhani participated in the development of the project. Seyedeh Neda Mousavi contributed to the final content, analyzed and interpreted the data, wrote the first draft of the manuscript. Seyedeh Neda Mousavi and Ali Awsat Mellati provided critical revision and important intellectual content. All authors have read and approved the final version of the manuscript.

Acknowledgments: The authors thank all the study participants for their collaboration. This study was extracted from the Master student thesis.

\section{References}


1. -World Health Organization. Global Reports on Diabetes. Geneva: World Health Organization; 2016.

2. Long -AN, Dagogo JS. Comorbidities of diabetes and hypertension: mechanisms and approach to target organ protection. J Clin Hypertens (Greenwich). 2011;13:244-51.

3. Parikh -NH, Parikh PK, C. Kothari. Indigenous plant medicines for health care: treatment of diabetes mellitus and hyperlipidemia. Chin J Nat Med. 2014;12:335-44.

4. Jay -MA, Ren J. Peroxisome proliferator-activated receptor (PPAR) in metabolic syndrome and type 2 diabetes mellitus. Curr Diabetes Rev. 2007;3:33-9.

5. Shidfar -F, Jazayeri Sh, Mousavi SN, et al. Dose supplementation with royal jelly improve oxidative stress and insulin resistance in type 2 diabetic patients? Iran j public Health. 2015;44:797-803.

6. Constantinou -PC, Papas A, Constantinou Al. Vitamin E and cancer: an insight into the anticancer activities of vitamin $\mathrm{E}$ isomers and analogs. Int $\mathrm{J}$ Cancer. 2008;123:739-52.

7. $10.1155 / 2009 / 818945$

Leonardini -A, Laviola L, Perrini S, A. et al (2009) Cross-Talk between PPARy and Insulin Signaling and Modulation of Insulin Sensitivity. PPAR Research 2009. .

8. Lorvand Amiri -H, Agah S, Tolouei Azar J, et al. Effect of daily calcitriol supplementation with and without calcium on disease regression in non-alcoholic fatty liver patients following an energyrestricted diet: Randomized, controlled, double-blind trial. Clin Nutr. 2017;36:1490-7.

9. Weindl -G, Schafer-Korting M, Schaller M, et al (2005) Peroxisome proliferator-activated receptors and their ligands: entry into the post-glucocorticoid era of skin treatment? Drugs 65: 1919-1934.

10. Rosen -ED, Spiegelman BM. PPAR gamma: a nuclear regulator of metabolism, differentiation, and cell growth. J Biol Chem. 2001;276:37731-4.

11. Ren -D, Collingwood TN, Rebar EJ, et al. PPAR gamma knockdown by engineered transcription factors: exogenous PPARgamma2 but not PPARgamma1 reactivates adipogenesis. Genes Dev. 2002;16:27-32.

12. Rubic -T, Lorenz RL. Downregulated CD36 and oxLDL uptake and stimulated ABCA1/G1 and cholesterol efflux as anti-atherosclerotic mechanisms of interleukin-10. Cardiovasc Res. 2006;69:527-35.

13. Nagashima $-K$, Lopez $C$, Donovan $D$, et al. Effects of the PPARgamma agonist pioglitazone on lipoprotein metabolism in patients with type 2 diabetes mellitus. J Clin Invest. 2005;115:1323-32.

14. Fang $-F$, Kang $Z$, Wong $C$. Vitamin $E$ tocotrienols improve insulin sensitivity through activating peroxisome proliferator-activated receptors. Mol Nutr Food Res. 2010;54:345-52.

15. Lee -J, Hong EM, Koh DH, et al. HMG-CoA reductase inhibitors (statins) activate expression of PPARalpha/PPARgamma and ABCA1 in cultured gallbladder epithelial cells. Dig Dis Sci. 2010;55:292-9.

16. Constantinou -PC, Papas A, Constantinou Al. Vitamin E and cancer: an insight into the anticancer activities of vitamin $\mathrm{E}$ isomers and analogs. Int $\mathrm{J}$ Cancer. 2008;123:739-52. 
17. Traber -MG, "Vitamin E," in Modern Nutrition in Health and Disease, ShilsME, ShikeM, A. C. Ross, B. Caballero, and R. J. Cousins, Eds., pp. 396-411, Lippincott Williams and Wilkins, Baltimore, Md, USA, 10th edition, 2006.

18. Stone -WL, Krishnan K, Campbell SE, et al. Tocopherols and the treatment of colon cancer. Ann N Y Acad Sci. 2004;1031:223-33.

19. Reboucas -L, Costa EN, Passos JM, et al. Real Time PCR and Importance of Housekeepings Genes for Normalization and Quantification of mRNA Expression in Different Tissues. Braz Arch Biol Technol. 2013;56:143-54.

20. Adams -SP, Tsang M, Wright JM. Lipid lowering efficacy of atorvastatin. Cochrane Database Syst Rev. 2012;12:12.

21. Issemann -I, Green S. Activation of a member of the steroid hormone receptor superfamily by peroxisome proliferators. Nature. 1990;347:645-50.

22. Omi -T, Brenig B, Spilar KS, et al. Identification and characterization of novel peroxisome proliferatoractivated receptor-gamma (PPAR-gamma) transcriptional variants in pig and human. J Anim Breed Genet. 2005;122:45-53.

23. Desvergne -B, Wahli W. Peroxisome proliferator-activated receptors: nuclear control of metabolism. Endocr Rev. 1999;20:649-88.

24. Bozaykut -P, Karademir B, Yazgan B, et al. Effects of vitamin E on peroxisome proliferator-activated receptor $\mathrm{Y}$ and nuclear factor-erythroid 2-related factor 2 in hypercholesterolemia-induced atherosclerosis. Free Radic Biol Med. 2014;70:174-81.

25. Ye -Y, Nishi SP, Manickavasagam S, et al. Activation of peroxisome proliferator-activated receptorgamma (PPAR-gamma) by atorvastatin is mediated by 15-deoxy-delta-12,14-PGJ2. Prostaglandins Other Lipid Mediat. 2007;84:43-53.

26. Landrier -F, Gouranton E, Yazidi C, et al. Adiponectin Expression Is Induced by Vitamin E via a Peroxisome Proliferator-Activated Receptor $\gamma$-Dependent Mechanism. Endocrinology. 2009;150:5318-25.

27. Diepeveen -SH, Verhoeven GW, Palen V J, et al. Effects of atorvastatin and vitamin E on lipoproteins and oxidative stress in dialysis patients: a randomized-controlled trial. J Intern Med. 2005;257:43845 .

28. Mita -T, Nakayama Sh, Abe H, et al. Comparison of effects of pitavastatin and atorvastatin on glucose metabolism in type 2 diabetic patients with hypercholesterolemia. J Diabetes Investig. 2013;4:297-303.

29. Khabaz -M, Rashidi M, Kaseb F, et al. Effect of Vitamin E on Blood Glucose, Lipid Profile and Blood Pressure in Type 2 Diabetic Patients. Iranian Journal of Diabetes Obesity. 2009;1:11-5.

30. Gazis -A, White DJ, Page SR, et al. Effect of oral vitamin E(alpha-tocopherol) supplementation on vascular endothelial function in Type 2 diabetes mellitus. Diabet Med. 1999;16:304-11.

31. Jain -SK, McVie R, Jaramillo JJ, et al. Effect of modest vitamin E supplementation on blood glycated hemoglobin and triglyceride levels and red cell indices in type I diabetic patients. J Am Coll Nutr. 
$1996 ; 15: 458$.

32. Manzella -D, Barbieri M, Ragno E, et al. Chronic administration of harmacologic doses of vitamin $E$ improves the cardiac autonomic nervous system in patients with type 2 diabetes. Am J Clin Nutr. 2001;73:1052-7.

33. Cinaz -P, Hasanoglu A, Bideci A, et al. Plasma and erythrocyte vitamin E levels in children with insulin dependent diabetes mellitus. J Pediatr Endocrinol Metab. 1999;12:193-6.

\section{Figures}

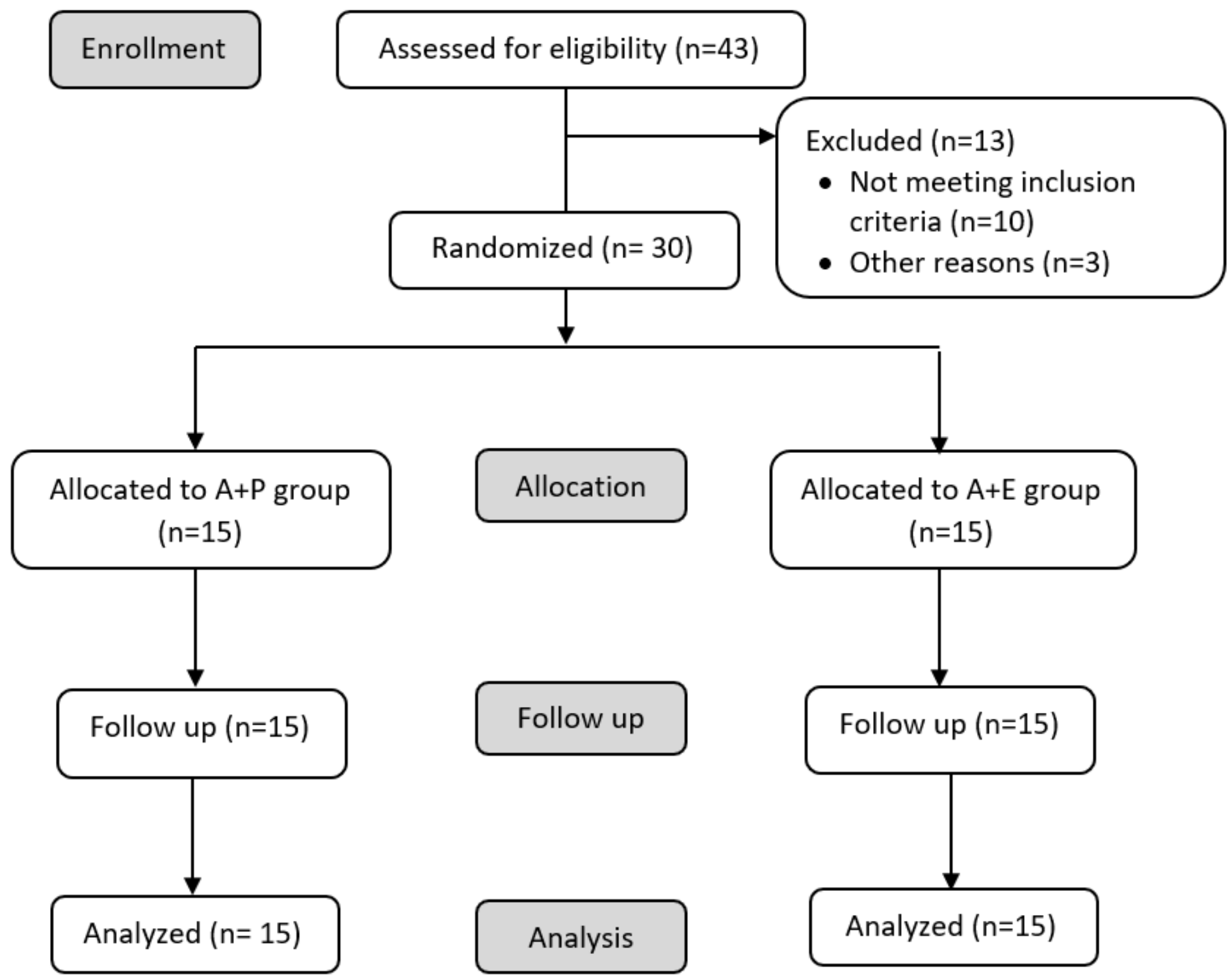

Figure 1

Screening, enrollment, random assignment, and follow-up of study participants 